\title{
Sexual and Marital Relationship Satisfaction in Parents of Children With Disabilities
}

\author{
Remigiusz Kijak ${ }^{1}$ \\ ${ }^{1}$ University of Warsaw, Poland
}

\begin{abstract}
HOW TO CITE:
Kijak, R. (2020).

Sexual and Marital Relationship

Satisfaction in Parents

of Children With Disabilities.

International Journal of Special

Education, 35(2), 41-51

CORRESPONDING AUTHOR:

Remigiusz Kijak;

r.kijak@uw.edu.pl

DOI:

https://doi.org/10.52291/

ijse.2020.35.12

COPYRIGHT STATEMENT:

Copyright: (C) 2020 Authors.

Open access publication under the terms and conditions of the Creative Commons

Attribution (CC BY)

license (http://creativecommons.

org/licenses/by/4.0/).
\end{abstract}

\section{ABSTRACT}

The purpose of this study was to determine the level of sexual satisfaction and type of relationship between spouses, and then to determine the correlation between these variables and independent variables. These include: disability type of the child, the number of children in the family, and the gender of the parents. The hypothesis was that 'the level of sexual satisfaction in parents is significantly related to the type of disability possessed by their children' and similarly it was found that disability type significantly affects the type of relationship between parents. The research was conducted using the Matched Marriage Questionnaire (MMQ) and the Sexual Satisfaction Scale (SSS). The data obtained in the study showed that most spouses experience high and average sexual satisfaction and no particular differences between men and women were observed. The differences appeared when analyzing parents of a child with autism. In this group the results were more diverse in the detailed descriptions of the scale. The results obtained regarding marital relationship satisfaction indicate a not very favorable picture of the relationships of the surveyed subjects.

Keywords: marital relationship satisfaction; sexual satisfaction; disability; intellectual disability; autism 


\section{INTRODUCTION}

Relationships between partners in close dyadic relationships are assessed primarily by analyzing the factors that guarantee success. In this regard, it is worth citing studies by Booth and White (1980), White and Hatcher (1984), Braun-Gałkowska (1985; 2003), Schoen and Weinick (1993), Logan, Kern, Curlette, Trad (1993), Holman et al. (2001) to name but a few. These studies point to a wide range of factors in the case of successful marriages or permanent partnerships. Communication is consistently identified by researchers as being of particular importance. The necessary components of communication include: empathy, emotional closeness, and openness. These factors constitute the quality of communication. Such studies as those cited previously also emphasize the idea that relationships between partners should include at least three dimensions, these are: reciprocity in communication, intimacy, and behavior during arguments. However, there is little research that takes into account an extremely important factor that affects the relationship between spouses and permanent partners, which is the disability of a child. In this regard, we can point to, among others, International (Del Fierro Avila, 2017) and Polish (Żyta, 2011; Pisula, 2011) studies. It can be concluded that having a child with developmental disorders (intellectual disabilities or autism) is associated with many challenges. Most parents of children that develop in a typical fashion do not encounter such difficulties. According to Ellis and Hirsh (2000), parents of children with developmental disabilities find it exceedingly difficult to cope with their child's developmental milestones, which results in increased levels of stress and impacts negatively on their marital relationship satisfaction or the continuation of their partnership. In a study of the literature, the level of dissatisfaction of being in a marital relationship for parents of children with pervasive developmental disorders is significantly higher due to multiple stressors when compared to parents of normally developing children (Beckman-Bell, 1991; Fisman \& Wolf, 1991; Johnson et al, 2003; Pisula, 2011; Poop, Robinson, Britner, \& Blank, 2014; Woodman, Mawdsely, $\&$ Hauser-Cram, 2015).

In addition, research has shown that dissatisfaction with being in a relationship may stem from the many nonspecific, recurring, and significant challenges associated with the responsibility of caring for a child with a disability (Pisula, 2011). Available research also suggests that commitment to the marital relationship may vary significantly on account of the gender of the parents. The issues discussed are how mothers and fathers cope with the stress of having a child with a disability (Pisula, 2011). Most often it is stress that affects their marital relationship (authors that have written about this, among others, include: Johnston et al., 2003; McCarthy, Cuskelly, Kraayenoord, \& Cohen, 2006).

Another article presents research on marital relationship satisfaction in the case of spouses who have a child with an intellectual disability or autism spectrum disorder (Leyser \& Kirk, 2011; Loiacono \& Allen, 2008). Marital relationship satisfaction depends on many factors - one of which may be family circumstances, especially issues of family demographics, others include: economics, number of children in the family, etc. (Janicka \& Liberska, 2014, p. 13). In this context, the process of the transmission of factors that affect the family strengthens the family or weakens it. The above assumption became the center of the issues considered and is the starting point of this research. Marital relationship satisfaction was diagnosed using the Matched Marriage $\mathrm{Qu}-$ estionnaire (KDM-2) developed by Mieczysław Plopa and Jan Rostowski. We can say that marital relationship satisfaction is a unifying term including such elements as: „sense of integration, satisfaction, happiness, adjustment and communication" (Spanier \& Lewis, 1980). One of the most important factors shaping the lives of the parents of children with intellectual disabilities is the child's traits including but not limited to: the degree of disability, the presence of strange, incomprehensible, and unacceptable behaviors, or the prominence of the disorder (Neik, et al., 2014). The higher the degree of the child's disability, the more difficult it is for parents to fulfill their parenting roles, and the higher the level of stress they experience (Upadhyay \& Singh, 2009).This consequently negatively affects their marital relationship (Stelter, 2014). An analysis of the literature also indicates that the quality of marital relationships is dependent on parents' judgment of their child (with an intellectual disability) (Baker et al., 2005; Hartley et al., 2011; Wymbs et al., 2008), and also correlates positively with feelings of sexual satisfaction in the relationship (Janicka \& Niebrzydowski, 1994).

A satisfying sex life plays an important role in a relationship; it strengthens the bonds between partners and correlates with the frequency of sexual activity (Kucharski \& Rzepa, 2017); positively affects the level of satisfaction within the relationship (Yucel \& Gassanov, 2010) 
and can increase the overall quality of an individual's life (Nomejko et al., 2012). It has also been shown that high self-esteem in women is associated with feelings of sexual desire and reaching orgasm (Borissova et al., 2001), as well as happiness experienced in the form of sexual satisfaction (Baumeister et al., 2003), and a sense of being loved (Kijak, 2020). Thus, an important component of sexuality is sexual satisfaction, understood as an attitude toward one's sex life, which is expressed through thoughts, behaviors, and emotions regarding one's; sexual attractiveness, sexual partners, and sex itself (Nomejko et al., 2012; Żak-Łykus \& Nawrat, 2013). Sexual satisfaction is determined by many factors, the most prominent of which is sex, which differentiates needs, desires, expectations, and feelings (Kijak, 2020; Yucel \& Gassanov, 2010). A meta-analysis of studies on men's and women's attitudes towards sex found that men were more accepting of premarital sex, sex without any type of commitment or masturbation. Women, on the other hand, more often declared anxiety connected with this area of activity and life (DeLamater \& Friedrich, 2002). The appearance of a child with a disability in the family also affects partners' sexual satisfaction (Kijak, 2019). Therefore, it was decided to research and analyze whether sexual satisfaction is differentially affected by having a child with an intellectual disability or autism spectrum development disorder, and additionally by age and sex. For this purpose, Deborah Davis' Sexual Satisfaction Scale (SSS) questionnaire was used (Davis et al., 2006).

\section{MARITAL/PARTNER SATISFACTION}

Researchers have highlighted the fact that a child with a disability can disrupt the relationship between parents due to several factors: unequal sharing of childcare responsibilities, lack of leisure time, the effects of the longterm burden that difficult situations create, and chronic stress caused by anxiety about the child's health (Taanila et al., 1996; Friedrich \& Friedrich, 1981). Parents of children with intellectual disabilities or autism experience increased levels of stress, present lower levels of sexual and marital relationship satisfaction (Friedrich \& Friedrich, 1981), and can experience relationship crises (Hodapp, 2007; Wymbs et al., 2008). Eddy and Walker (1999), looks at the impact of a chronically ill child on the quality of the parents' marriage. They found that opinions on relationship quality for the group of parents with sick children did not differ significantly from those of parents with healthy children, and that having a sick child may be a neutral situation and will not necessarily negatively impact on the relationship between parents. Similar results were obtained by researchers working on the problem of divorce and separation among families raising a child with an intellectual disability (Hodapp, 2007; Witt et al., 2003). Similar trends have been shown in Polish research conducted by among others, Stelter (2013).

\section{SEXUAL SATISFACTION}

Sexual satisfaction is an essential component of human sexuality. It is also a key factor in the overall quality of life for individuals. For example, better physical and mental health and overall well-being and quality of life are associated with high sexual satisfaction. Similarly, aspects pertaining to the relationship such as high relationship satisfaction, communication with the partner, and sexual assertiveness have been shown to be linked to higher sexual satisfaction. Other variables such as social support, good relationships with children and family, and higher socioeconomic status are also associated with high levels of sexual satisfaction (Sánchez-Fuentes, Santos-Iglesias, $\&$ Sierra, 2014). The review revealed the complexity and importance of sexual satisfaction, which was associated with the following variables and factors: a) individual variables such as socio-demographic and psychological characteristics as well as physical and psychological health status; $b$ ) variables associated with intimate relationships and sexual response; c) factors related to social support and family relationships; and d) cultural beliefs and values such as religion.

In conclusion, it was observed that sexual satisfaction is a key factor in individuals' sexual health and overall well-being (Sánchez-Fuentes, Santos-Iglesias \& Sierra, 2014). It is important to emphasize that sexual satisfaction does not mean the absence of sexual dissatisfaction or the absence of sexual dysfunction (Byers,1999). Sexual satisfaction is an integral component of sexual health and well-being. Despite its context-dependent nature, sexual satisfaction is often considered solely in terms of physiology, based on the medical model of sexual functioning popularized by Masters and Johnson (Henderson et al., 2008). Research on the topic of sexual satisfaction indicates that it is highly correlated with the quality of a relationship. Higher levels of sexual satisfaction are associated with a higher propensity for commitment and the desire to remain in a stable relationship. 
From the works of Polish authors, it seems that the studies by Nomejko and Dolińska-Zygmunt (2014) and Janowski and Czyżkowska (2013) should be given special attention and focus. Nomejko and Dolińska-Zygmunt undertook the construction of a tool that is an attempt to combine SSS with healthcare, to be understood in a holistic manner (physical, emotional, mental, social aspects). It is similar to the evaluation of one's own sexuality (attractiveness and sexual activity) but does not refer to an evaluation of a sexual relationship with a particular partner. Janowski and Czyżkowska, on the other hand, developed a Polish version of the questionnaire made by Meston and Trapnell (2005) and used it to measure sexual satisfaction of women in the area of fulfillment only (evaluation of satisfaction within the entirety of sexual functioning), communication (communication between partners in matters related to sex and revealing deep feelings or emotions) and matching (similarity between partners in terms of beliefs, needs, related to sexuality). The level of sexual satisfaction may also be related to age, sexual sensitivity, ways of regulating fertility (Harris, after Grabowska, 2014, p. 170), or to attitudes, beliefs, value systems (Kohlberg, after Grabowska, 2014, p. 169; cf. Komorowska-Pudło, 2014a), piety (Grabowska, 2014, p. 172), or to different experiences e.g., the disability of a child in the family (see Komorowska-Pudło, 2014b). According to researchers (Butzer \& Campbell, 2008; Litzinger \& Gordon, 2005), the level of sexual satisfaction is a key component of relationship satisfaction. The higher that respondents rate sex life, the higher the scores that can be observed in the area of relationship satisfaction. On the other hand, relationship satisfaction affects various aspects of a person's life, including sexual satisfaction (Rostowski, 1986). There is a consensus among researchers regarding the link between sexual satisfaction and marital relationship satisfaction sub-scales (intimacy, passion, commitment). Intimacy, the ability to communicate in a relationship with a partner, and the ability to communicate one's needs openly, may contribute to heightened arousal and thus an overall sense of greater sexual satisfaction (Sprecher \& McKinney, 1993). Intimacy also correlates positively with commitment (Sprecher, Barbee, \& Schwartz, 1995). Just as sexual satisfaction enhances commitment, strong commitment increases the intensity of behaviors designed to improve the quality of intercourse between partners. Passion also positively correlates with sexual satisfaction (Specjalski, et al. 2014) and is a function of changing intimacy levels, hence passion will remain low when intimacy is stable (Specjalski, et al. 2014).

\section{METHODS, DATA COLLECTION, AND PROCEDURES: RESEARCH TOOLS}

The research was conducted in the Podkarpacie Voivodeship (one of the 17 administrative regions of Poland). The reasons for this choice were that it is an area with a strongly right-wing electorate, as well as with a strong attachment to tradition and religion. The research was conducted in several groups of parents who have a child with a disability - autism or intellectual disability. The child's disability was one of the independent variables selected for the study. Two indicators were used in the study - families of a child with autism or families of a child with intellectual disability. A total of 120 pairs of parents were surveyed ( 240 parents - 120 women and 120 men). Respondents for the study were enrolled through the principals of the schools in which the study was conducted. In addition, the gender of the parents and the number of children in the family were taken into account as variables. The respondents declared their own gender and the number of children they have in their care. All parents completed the Matched Marriage Questionnaire (Mieczysław Plopa, Jan Rostowski 2006) and the Sexual Satisfaction Questionnaire (Davis et al., 2006). Several research questions were formulated.

- What is the level of marital relationship satisfaction for parents of children with disabilities?

- Is there (and if so what kind) a relationship between the gender of the parents surveyed and the type of intimate bond they share?

- Are there (and if so what are they) differences that exist between the type of intimate bond parents share and the type of disability of the child?

- Does (and if it does to what extent) the number of children in a family differentiate the type of ties that parents share?

- What is the level of sexual satisfaction of the surveyed parents of children with disabilities?

The variables adopted in this study are illustrated in Table 1.

\section{SOURCE: OWN RESEARCH}

The tool used in conducting the research for this study was the Matched Marriage Questionnaire (KDM-2) developed by Mieczysław Plopa and Jan Rostowski in 2006. 


\begin{tabular}{|c|c|c|c|c|c|}
\hline Measurement & Indicators & $\begin{array}{l}\text { Dependent } \\
\text { variable }\end{array}$ & $\begin{array}{l}\text { Independent } \\
\text { variable }\end{array}$ & Indicators & Measurement \\
\hline $\begin{array}{l}\text { The Matched } \\
\text { Marriage Questionnaire } \\
\text { (Mieczysław Plopa, } \\
\text { Jan Rostowski 2006) }\end{array}$ & $\begin{array}{l}\text { - Intimacy } \\
\text { - Disappointment } \\
\text { - Self-actualization } \\
\text { - Similarity }\end{array}$ & $\begin{array}{l}\text { Marital } \\
\text { relationship } \\
\text { satisfaction }\end{array}$ & $\begin{array}{l}\text { Disability } \\
\text { of the child }\end{array}$ & $\begin{array}{l}\text { Intellectual } \\
\text { disability } \\
\text { Autism }\end{array}$ & \multirow[t]{2}{*}{ Particulars } \\
\hline $\begin{array}{l}\text { Deborah Davis' } \\
\text { Sexual Satisfaction } \\
\text { Scale (SSS) } \\
\text { (Davis et al., 2006) }\end{array}$ & $\begin{array}{l}\text { - General } \\
\text { - Physical } \\
\text { - Emotional } \\
\text { - Sense of control }\end{array}$ & Sexual satisfaction & $\begin{array}{l}\text { Number } \\
\text { of children } \\
\text { Sex }\end{array}$ & $1 / 2 / 3>M / F$ & \\
\hline
\end{tabular}

This questionnaire contains 32 statements referring to the real marital status of the examined couples and is divided by sex. The respondent's task is to circle one of the five answers - each one is assigned a numerical value: 1 - „I completely agree”, 2 - „I agree”, 3 - „I have no opinion”, 4 - „I disagree”, 5 - „I completely disagree”. Each statement in the KDM-2 is assigned to one of the categories which are the relationship types in marriage. „The overall raw score is obtained by totaling the raw scores of the intimacy, similarity, self-actualization, and disappointment scales" (Plopa, 2008, p. 95). The higher the raw score, the better the quality of the marriage. The raw scores are carried out to the sten score, which holds 10 units. The normalized sten scores are divided according to sex. The Matched Marriage Questionnaire is divided by the gender of the respondent, containing a separate set of statements for wives and husbands. Additionally, the KDM-2 is accompanied by particulars asking the respondent to indicate: the number of children they have, their sex, and what disability the child has. The first step in the analysis of the survey, leading to the reading of the survey results, was to enter all the responses given by the respondents into the appropriate boxes in the table. The statements from the questionnaire were separated into their respective satisfaction indicators: - Intimacy Scale: 1, 5, 10, 14, 19, 23, 27, 31; - Disappointment Scale: 2, $6,8,11,15,18,20,24,28,32$; - Self-realization scale: $3,7,12,16,21,25,29$; - Similarity scale: 4, 9, 13, 17, $22,26,30$. All the answers that the subject had to choose from are assigned a numerical value: $A=5, B=4, C=3$, $\mathrm{D}=2, \mathrm{E}=1$. The only exception in terms of value is the disappointment scale, which takes the numerical values: $\mathrm{A}=1, \mathrm{~B}=2, \mathrm{C}=3, \mathrm{D}=4, \mathrm{E}=5$. The next step is to add up the values of the given statement and calculate their raw score, which in turn was used to determine the sten norm. The final step is to calculate the overall raw score, which is the result of adding together the raw scores of the satisfaction indicators. The sten scale has ten units in it, stens
1-2 indicate extremely low scores, stens 3-4 indicate low scores, stens 5-6 indicate average scores, stens 7-8 indicate high scores, and stens 9-10 indicate extremely high scores. The scores for each of the satisfaction indicators fall into different score ranges.

The level of sexual satisfaction of the respondents was determined with the use of the Sexual Satisfaction Scale (SSS) by Davis (Davis et al., 2006). By using this scale, apart from total sexual satisfaction (general), it is possible to compare correlations of particular spheres of sexual satisfaction in respondents: physical, emotional and in the range of sense of control, with particular elements defining the quality of a marital relationship between men and women. Sexual physical satisfaction is connected, as per Davis's (2006) theory, with the evaluation of the quality of sexual experiences in the relationship, skills in this sphere and realization of sexual needs. Emotional satisfaction includes satisfaction with affective feelings toward sex and partner behavior, and feelings toward a partner. Satisfaction with a sense of control includes satisfaction with one's assessment of one's influence on how, when, and if sexual contact in the relationship will take place. People surveyed responded to the statements in the questionnaire by selecting one of five responses ranging from „strongly disagree” to „strongly agree” depending on their own assessment of their sexual experiences and needs. The raw scores obtained in the study, when transformed into sten scores and data, made it possible to determine the level of sexual satisfaction they felt.

\section{RESULTS}

Let us begin by discussing the sense of sexual satisfaction of the surveyed parents. The data obtained in the study shows that spouses experience rather average sexual satisfaction. 


\section{SENSE OF SEXUAL SATISFACTION PROVIDED DATA IS ROUNDED UP}

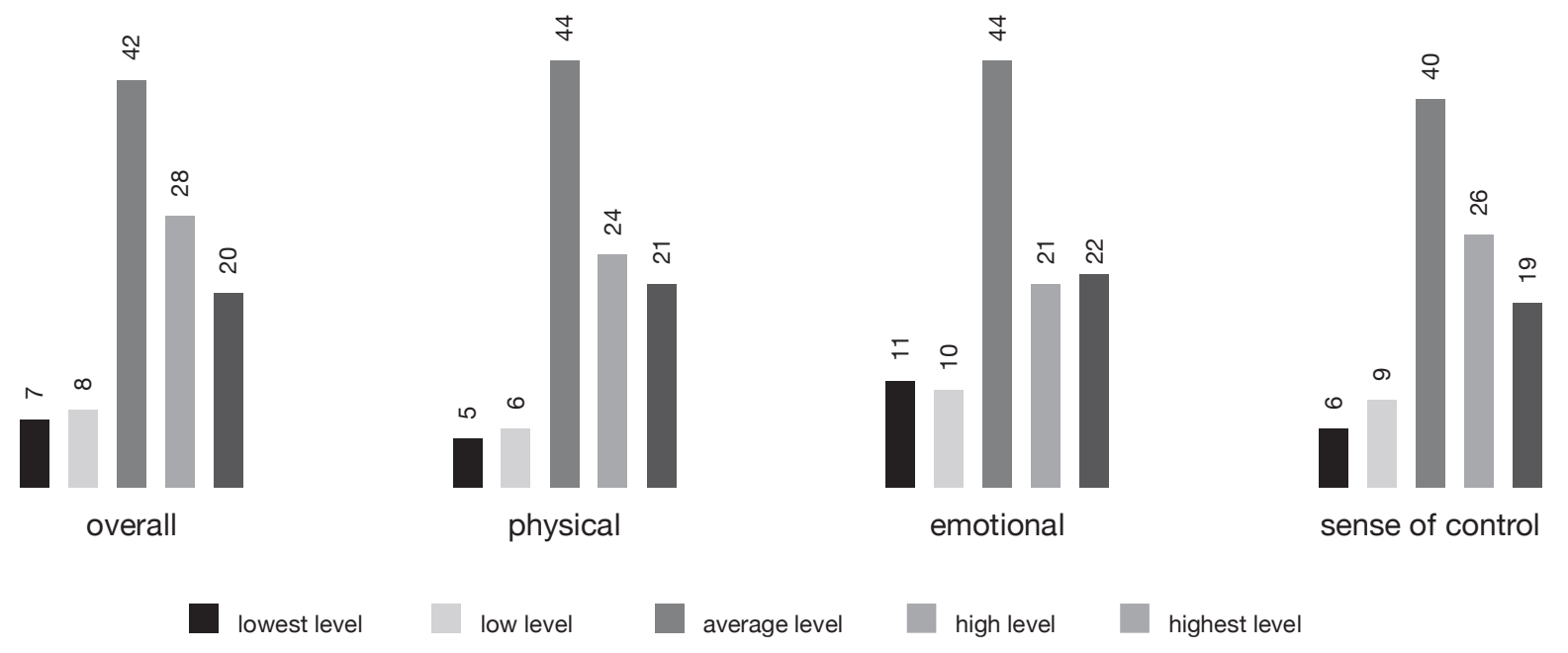

Figure 1. Sense of sexual satisfaction among surveyed spouses who have a child with a disability.

Considering the detailed components of the satisfaction in question, some differences can be observed. The highest level of satisfaction was shown by the respondents in the physical aspect and the sense of control. The lowest level of satisfaction was shown by the respondents is in the emotional aspect.

When broken down by the gender of the individuals surveyed, the results are distributed very similarly, but some differences can be seen at the statistical level. For example, that three quarters of men and almost two -thirds of women obtained results indicating an average level of physical satisfaction. Men are more satisfied in this case than women $(\mathrm{R}=-0.15 ; \mathrm{p}=0.02)$. Fairly low scores were obtained by respondents of both genders when analyzing their sexual satisfaction in terms of sense of control. The lowest level of sexual satisfaction among the three components was obtained by spouses in the emotional aspect. The data shows that women are less satisfied in this area of sexual relations than men (at the trend level $\mathrm{R}=-0.12 ; \mathrm{p}=0.07$ ). Only slightly more than $20 \%$ of female spouses obtained a high and exceedingly high level of emotional satisfaction, while such satisfaction was obtained by $30 \%$ of male respondents.

Measured by means of the Sexual Satisfaction Scale (SSS), the type of children's disability proved to be statistically significant and play an important role. The data shows that parents of autistic children have lower overall sexual satisfaction, while parents of children with intel- lectual disabilities score higher in this aspect. In the case of women, this relationship is slightly stronger $(\mathrm{R}=0.61)$ than in the case of men $(\mathrm{R}=0.57)$. It is also worth pointing out that there was a positive correlation between sexual satisfaction and marital relationship satisfaction, although differences between genders were observed. Sexual satisfaction correlated more with marital relationship satisfaction for men than for women.

The following tables (2-4) present descriptive statistics (for KDM-2 scores in the form of point values) and frequency distributions (for KDM-2 scores in the form of a classification that takes into account the three levels of a trait). Such summaries were prepared both for the total number of respondents and for each category of their gender and the type of disability of their children. In subsequent compilations of the KDM-2 scores with other variables, the exact point value was considered, i.e., at the highest possible (quotient) level of measurement. It was therefore necessary to check whether the KDM-2 scales had distributions close to normal distribution - the Shapiro-Wilk test was used for this purpose. In all cases, the detailed scales of the questionnaire (intimacy, disappointment, self-actualization, and similarity) did not have normal distributions, while the overall scale had such a distribution. Therefore, at a further stage of analysis, the non-parametric Mann -Whitney $U$ test was used in the first case and the parametric Student's t test in the second. To illustrate this data, only a table is presented for total subjects surveyed and divided by the sex of the spouses surveyed. 


\begin{tabular}{|c|c|c|c|c|c|c|}
\hline KDM-2 - scale: & $\mathbf{M}$ & Me & Min. & Max. & SD & Normality of Distribution \\
\hline Intimacy (8-40) & 18.56 & 18.00 & 8.00 & 36.00 & 5.85 & $W=0.97, p<0.01$ \\
\hline Disappointment (10-50) & 29.29 & 30.00 & 10.00 & 50.00 & 11.07 & $W=0.95, p<0.01$ \\
\hline Self-actualization (7-35) & 16.50 & 16.00 & 7.00 & 32.00 & 4.35 & $W=0.97704, p<0.01$ \\
\hline Similarity (7-35) & 15.87 & 15.00 & 7.00 & 32.00 & 4.83 & $W=0.94646, p<0.01$ \\
\hline General (32-160) & 81.65 & 83.00 & 40.00 & 129.00 & 15.34 & $W=0.99, p=0.18$ \\
\hline
\end{tabular}

Table 3.

SCALE SCORES OF THE MATCHED MARRIAGE QUESTIONNAIRE - DESCRIPTIVE STATISTICS - WOMEN

\begin{tabular}{|c|c|c|c|c|c|c|}
\hline KDM-2 - scale: & $\mathbf{M}$ & Me & Min. & Max. & SD & Normality of Distribution \\
\hline Intimacy (8-40) & 18.25 & 17.00 & 8.00 & 33.00 & 5.93 & $W=0.96, p<0.01$ \\
\hline Disappointment (10-50) & 28.83 & 29.00 & 10.00 & 48.00 & 11.09 & $W=0.95, p<0.01$ \\
\hline Self-actualization (7-35) & 16.30 & 16.00 & 7.00 & 32.00 & 4.30 & $W=0.98, p<0.04$ \\
\hline Similarity (7-35) & 15.53 & 15.00 & 7.00 & 27.00 & 4.65 & $W=0.93, p<0.01$ \\
\hline General (32-160) & 81.25 & 82.50 & 44.00 & 129.00 & 15.41 & $W=0.99, p=0.30$ \\
\hline
\end{tabular}

Table 4.

SCALE SCORES OF THE MATCHED MARRIAGE QUESTIONNAIRE - DESCRIPTIVE STATISTICS - MEN

\begin{tabular}{|c|c|c|c|c|c|c|}
\hline KDM-2 - scale: & $\mathbf{M}$ & Me & Min. & Max. & SD & Normality of Distribution \\
\hline Intimacy (8-40) & 18.87 & 18.00 & 8.00 & 36.00 & 5.78 & $W=0.97, p<0.01$ \\
\hline Disappointment (10-50) & 29.74 & 30.50 & 10.00 & 50.00 & 11.09 & $W=0.95, p<0.01$ \\
\hline Self-actualization (7-35) & 16.71 & 16.00 & 7.00 & 32.00 & 4.40 & $W=0.97, p<0.01$ \\
\hline Similarity (7-35) & 16.21 & 15.00 & 7.00 & 32.00 & 5.01 & $W=0.95, p<0.01$ \\
\hline General (32-160) & 82.04 & 83.50 & 40.00 & 116.00 & 15.32 & $W=0.99, p=0.46$ \\
\hline
\end{tabular}

Table 5.

RESPONDENTS' PERCEIVED LEVEL OF SIMILARITY - COMPARISON BETWEEN PARENTS OF CHILDREN WITH AUTISM AND INTELLECTUAL DISABILITIES IN THE FEMALE GROUP

\begin{tabular}{|c|c|c|c|c|c|c|}
\hline \multirow[b]{2}{*}{ Type of disability: } & \multicolumn{6}{|c|}{ Level of Disappointment (scale of 8-40): } \\
\hline & $\mathbf{N}$ & $\mathbf{M}$ & Me & Min. & Max. & SD \\
\hline Autism & 60 & 36.35 & 38.00 & 19.00 & 48.00 & 7.50 \\
\hline Intellectual disability & 60 & 21.32 & 19.50 & 10.00 & 45.00 & 8.76 \\
\hline Total & 120 & 28.83 & 29.00 & 10.00 & 48.00 & 11.09 \\
\hline Statistical Significance: & \multicolumn{6}{|c|}{$Z=7.42, p<0.01$} \\
\hline
\end{tabular}




\begin{tabular}{l|c|c|c|c|c|c}
\hline & \multicolumn{9}{|c}{ Level of Disappointment (7-35 scale): } \\
\hline Type of disability: & N & M & Me & Min. & Max. & SD \\
\hline Autism & 60 & 16.48 & 15.00 & 8.00 & 27.00 & 4.50 \\
\hline Intellectual disability & 60 & 14.58 & 14.00 & 7.00 & 27.00 & 4.65 \\
\hline Total & 120 & 15.53 & 15.00 & 7.00 & 27.00 & 4.65 \\
\hline Statistical Significance: & \multicolumn{7}{|c|}{ Z=2.60, $\mathbf{p}<\mathbf{0 . 0 1}$} \\
\hline
\end{tabular}

\begin{tabular}{l|c|c|c|c|c|c}
\hline & \multicolumn{7}{|c}{ Level of Disappointment (scale 32-160): } \\
\hline Type of disability: & N & M & Me & Min. & Max. & SD \\
\hline Autism & 60 & 76.45 & 75.00 & 44.00 & 129.00 & 18.43 \\
\hline Intellectual disability & 60 & 86.05 & 85.50 & 51.00 & 109.00 & 9.62 \\
\hline Total & 120 & 81.25 & 82.50 & 44.00 & 129.00 & 15.41 \\
\hline Statistical Significance: & \multicolumn{7}{|c|}{ t=3.58, p<0.01 } \\
\hline
\end{tabular}

\begin{tabular}{l|c|c|c|c|c|c}
\hline & \multicolumn{9}{|c}{ Level of Disappointment (scale of 8-40): } \\
\hline Type of disability: & N & M & Me & Min. & Max. & SD \\
\hline Autism & 60 & 37.45 & 39.00 & 17.00 & 50.00 & 7.42 \\
\hline Intellectual disability & 60 & 22.03 & 20.00 & 10.00 & 46.00 & 8.49 \\
\hline Total & 120 & 29.74 & 30.50 & 10.00 & 50.00 & 11.09 \\
\hline Statistical Significance: & \multicolumn{7}{|c|}{ Z=7.62, p<0.01 } \\
\hline
\end{tabular}

Table 9:

PERCEIVED LEVEL OF DISAPPOINTMENT BY RESPONDENTS - COMPARISON OF PARENTS ACCORDING TO THE NUMBER OF CHILDREN IN THE MALE GROUP

\begin{tabular}{l|c|c|c|c|c|c}
\hline & \multicolumn{9}{|c}{ Level of Disappointment (scale of 8-40): } \\
\hline Number of Children: & N & M & Me & Min. & Max. & SD \\
\hline 1-2 children & 37 & 31.14 & 33.00 & 12.00 & 44.00 & 9.76 \\
\hline 3 or more children & 23 & 24.87 & 23.00 & 10.00 & 46.00 & 11.39 \\
\hline Total & 60 & 28.73 & 29.50 & 10.00 & 46.00 & 10.77 \\
\hline Statistical Significance: & \multicolumn{7}{|c|}{ Z=2.21, $\mathbf{p = 0 . 0 3}$} \\
\hline
\end{tabular}


The results showed that nearly $61.7 \%$ of the women surveyed scored highly on the disappointment scale, and the same was true among the men surveyed, nearly $63 \%$ of whom were disappointed in the relationship they were creating. The results were better for the intimacy scale.

Significant differences were observed in the study of marital relationship satisfaction and the type of disability of the child. The Mann-Whitney $U$ test result also showed statistically significant $(\mathrm{p}<0.05)$ differences between the compared groups of subjects. Higher levels of disappointment were noted in parents of children with autism. This is illustrated in table 5 .

The Mann-Whitney U test result also showed statistically significant $(\mathrm{p}<0.05)$ differences between the comparison groups. A higher level of similarity was found among parents of children with autism. This was interesting considering the fact that most of the parents studied were characterized by a high level of disappointment with their own marriage, independent from having an autistic child. As the research indicates, having an autistic child can be more stressful for parents and have a destabilizing effect on emotional and affectional bonding. It was also interesting that the same parents, despite the feeling of disappointment in their relationship, had a fairly successful sex life (the level of general satisfaction at the high and very high levels were declared by $42 \%$ of respondents). Respondents were generally satisfied on both the physical and sense of control scales. See table 6 .

A surprising discovery in the interpretation of the material obtained was that parents of children with autism were characterized by a lower level of matching relationships than parents of children with intellectual disabilities. Further studies and surveys concerning this issue could be their own research project. These links were obtained by using the Student t-test for independent groups. The test showed statistically significant $(p<0.05)$ differences between the compared groups of respondents, in which the lower match level was characteristic of parents of children with autism. See table 7.

The Mann-Whitney U test result also showed statistically significant $(\mathrm{p}<0.05)$ differences between the compared groups of subjects. Higher levels of disappointment were noted in parents of children with autism.

The Mann-Whitney $U$ test result also showed other statistically significant $(\mathrm{p}<0.05)$ differences between the compared groups of subjects. A higher level of disappointment was observed in parents that have 1-2 children. This relationship is shown in Table 8. A statistically significant pattern was revealed in the fathers studied. It turns out that male respondents were additionally more disappointed in the relationship when there was more than one child in the family. Thus, the level of disappointment among the men surveyed was influenced by the type of disability of the child (autism) and additionally, disappointment appeared more often in larger families (3 and more children).

The study found no other statistically significant differences, so these calculations were not reported in the other data sets. The assumed relationships between the gender of the parents surveyed and the level of marital relationship satisfaction, as well as differences related to the number of children in the family and the other (except for the category of disappointment) components of sexual satisfaction were not confirmed by the research.

\section{CONCLUSION}

A study conducted within a group of Polish parents of a child with an intellectual disability or with autistic developmental spectrum disorder, indicated that they achieved average levels of satisfaction on both the sexual satisfaction and marital relationship satisfaction scales. Both of the questionnaires used are useful for research and clinical practice. The review revealed that sexual satisfaction and marital relationship satisfaction were influenced not only by individual and relational factors, but also by more distant variables related to the community of the individuals e.g., number of children in the family. Considering that child disability (Akkuş et al., 2010) is associated with difficulties in maintaining an intimate relationship (Moin, Duvdevany, \& Mazor, 2009) the results obtained from the study indicated that having a child with a disability - especially with autism spectrum developmental disorder - is a predictor of sexual satisfaction levels. It was revealed that in all components of marital relationship satisfaction, a link was revealed between said components and the type of disability of the child. The relationship was more difficult for parents with an autistic child. Similarly, although this was not the focus of the study, depression, anxiety, and stress operate and are associated with decreased sexual arousal (Lykins, Janssen, Newhouse, Heiman, \& Rafaeli, 2012) and difficulty communicating with partners (Scott et al., 
2012), which were shown to lead to decreased marital relationship satisfaction.

The findings of this research are important for parents but also for therapists and psychologists who should consider this aspect for families of a child with disabilities before they proceed with the diagnosis of the family environment. They should promote communication between partners about their sexual concerns, expectations and being in a relationship. It would now be interesting to see research on the role of the sexual attitudes (Hurlbert et al., 1993) and self-esteem (Higgins et al., 2011) of parents of a child with a disability. This could reveal in more detail the relationship between such variables and sexual and marital relationship satisfaction.

\section{ACKNOWLEDGEMENT}

None.

\section{DISCLOSURE STATEMENT}

No potential conflict of interest was reported by the authors.

\section{FUNDING}

None.

\section{REFERENCES}

Akkuş, Y., Nakas, D., \& Kalyoncu, U. (2010). Factors affecting the sexual satisfaction of patients with Rheumatoid Arthritis and Ankylosing Spondylitis. Sexuality and Disability, 28, 223-232.

Baker, B. L., Blacher, J., \& Olsson M. B. (2005), Preschool children with and without developmental delay: Behavior problems, parents' optimism and well-being. Journal of Intellectual Disability Research, 49, 8, 575-590.

Beckman-Bell, P. J. (1991). Comparison of mothers' and fathers' perceptions of the effect of young children with and without a disability. American Journal on Mental Retardation, 95(5), 585-595.

Booth, A., \& White, L. (1980). Thinking about divorce. Journal of Marriage and the Family, 42, 605-616.

Borrisova, A. M., Kovatcheva, R., Shinkov, A., \& Vukov, M. (2001). A study of the psychological status and sexuality in middle-aged Bulgarian women: significance of hormone replacement therapy (HRT). Maturitas, 39, 177-183.

Braun-Gałkowska, M. (1985). Miłość aktywna. Psychiczne uwarunkowania powodzenia małżeństwa. Warszawa: Instytut Wydawniczy PAX

Braun-Gałkowska, M. (2003). Psychoprofilaktyka życia rodzinnego. In Janicka, I., Rostowska, T. (eds.), Psychologia w służbie rodziny. Łódź: Wydawnictwo Uniwersytetu Łódzkiego.

Butzer, B., \& Campbell, L. (2008). Adult attachment, sexual satisfaction and relationship satisfaction: A study of married couples. Personal Relationships, 15, 141-154

Byers, E. S. (1999). The Interpersonal Exchange Mode I of Sexual Satisfaction: Implications for Sex Therapy with Couples. Canadian Journal of Counselling, 33(2), 95-111.

Byra, S., \& Parchomiuk, M. (2015). Przywiązanie a satysfakcja małżeńska współmałżonków osób z niepełnosprawnością ruchową. Studia nad Rodziną, XIX 2(37).

Davis, D., Shaver, P. R., Widaman, K. F., Vernon, M. L., Follette W. C., \& Beitz, K. (2006). "I can't get no satisfaction”: Insecure attachment, inhibited sexual communication, and sexual dissatisfaction. Personal Relationships, 13, 465-483.

Del Fierro Avila, J. (2017). Stress and Marital Satisfaction of Parents with Children with Fragile X Syndrome. Walden Dissertations and Doctoral Studies. 3488. Available from: https://scholarworks.waldenu.edu/dissertations/3488.

DeLamater, J., \& Friedrich, N. W. (2002). Human sexual development. Journal of Sex Research, 39, 1, 10-14.

Ellis, J., \& Hirsch, J. (2000). Reasons for living in parents of developmentally delayed children. Research in Developmental Disabilities, 21(4), 323-327.

Fisman, S. N., Wolf, L. C., \& Noh, S. (1989). Marital intimacy in parents of exceptional children. The Canadian Journal of Psychiatry, 34(6), 519-525.

Friedrich, W. N., \& Friedrich, W. L. (1981). Psychosocial assets of parents of handicapped and non-handicapped children. American Journal of Mental Deficiency, 85, 551-553.

Hartley, S. L., Barker, E. T., Seltzer, M. M., Floyd, F. J., \& Greenberg, J. S. (2011). Marital satisfaction and parenting experiences of mothers

and fathers of adolescents and adults with autism spectrum disorders. American Journal of Intellectual and Developmental Disabilities, 116, 81-95.

Henderson, A. W., Lehavot, K., \& Simoni, J. M. (2008). Ecological Models of Sexual Satisfaction among Lesbian/Bisexual and Heterosexual Women. Archives of Sexual Behavior, 38(1), 50-65.

Hodapp, R. M. (2007. Families of persons with Down syndrome: New perspectives, findings, and research and service needs. Mental Retardation and Developmental Disabilities Research Reviews, 3, 279-287.

Holman, T. B., Brich, P. J., Caroll, J. S., Doxey, C., Larson, J. H., \& Linford, S. T. (2001). Premarital prediction of marital quality or breakup. Research theory and practice. Dordrecht, Netherlands: Kluwer Academic Publishers.

Janicka, I., \& Liberska, H. (2014). Psychologia rodziny. Wstęp, Warszawa: Wydawnictwo Naukowe PWN, s. 13.

Janicka, I., \& Niebrzydowski, L. (1994). Psychologia małżeństwa, Łódź: Wydawnictwo Uniwersytetu Łódzkiego.

Janowski, K., \& Czyżowska, A. (2013). Właściwości psychometryczne polskiej wersji skali zadowolenia z życia seksualnego dla kobiet.

Przegląd Seksuologiczny, 36, s. 3-10. 
Johnson, C., Hessl, D., Blasey, C, Eliez, S., Erba, H., Dyer-Friedman, J., Glasser, B., \& Reiss, A. (2003). Factors associated with parenting stress in mothers of children with fragile x syndrome. Journal of Developmental \& Behavioral Pediatrics, 24(4), 267-275.

Kijak, R. (2020). Close Intimate Relations between People with Intellectual Disabilities - Constructivist Research: The Polish Perspective. International Journal of Special Education, 1, 54-61.

Kijak, R. (2019), Rodzice z niepełnosprawnością intelektualną. Warszawa: PWN

Kucharski, Sz., \& Rzepa, T. (2017). Samoocena i jej komponenty a satysfakcja z życia seksualnego. Psychoseksuologia, 6(3).

Leyser, Y., \& Kirk, R. (2011). Parents' Perspectives on Inclusion and Schooling of Students with Angelman Syndrome: Suggestions for Educators. International Journal of Special Education, 26(2), 79-91.

Litzinger, S., \& Gordon, K. C. (2005). Exploring relationships among communication, sexual satisfaction, and marital satisfaction. Journal of Sex \& Marital Therapy, 31, 409-424.

Logan, E., Kern, R., Curlette, W., \& Trad, A. (1993). Couples adjustment, life-style similarity, and social interest. Individual Psychology, 49, 456-467.

Loiacono, V., \& Allen, B. (2008). Are special education teachers prepared to teach the increasing number of students diagnosed with autism? International Journal of Special Education 23(2), 120-127.

Lykins, A. D., Janssen, E., Newhouse, S., Heiman, J. R., \& Rafaeli, E. (2012). The effects of similarity in sexual excitation, inhibition, and mood on sexual arousal problems and sexual satisfaction in newlywed couples. Journal of Sexual Medicine, 9, 1360-1366.

McCarthy, A., Cuskelly, M., van Kraayenoord, C. E., \& Cohen, J. (2006). Predictors of stress in mothers and fathers of children with fragile X syndrome. Research in Developmental Disabilities, 27(6), 688-704.

Moin, V., Duvdevany, I., \& Mazor, D. (2009). Sexual identity, body image and life satisfaction among women with and without physical disability. Sexuality and Disability, 27, 83-95.

Nomejko, A., \& Dolińska-Zygmunt, G. (2014). The Sexual Satisfaction Questionnaire - psychometric properties. Polish Journal of Applied Psychology, 12(3), 60.

Nomejko, A., Dolińska-Zygmunt, G., \& Zdrojewicz, Z. (2012). Poczucie jakości życia a satysfakcja z życia seksualnego - badania własne. Seksuologia Polska, 10(2), 54-60.

Neik, Tina Ting Xiang; Lee, Lay Wah; Niska, Hui Min; Chia, Noel Kok Hwee; Chua, Arnold Chee Keong (2014). Prevalence, diagnosis, treatment and research on autism spectrum disorders (ASD) in Singapore and Malaysia. International Journal of Special Education, 29(3), 82-92.

Pisula, E. (2011). Parenting stress in mothers and fathers of children with Autism Spectrum Disorders, a comprehensive book on Autism Spectrum Disorders. Available from: https://www.intechopen.com/books/a-comprehensive-book-on-autism-spectrum-disorders/parenting-stress-in-mothers-and-fathers-of-children-with-autism-spectrum-disorders.

Poop, J. M., Robinson, J. L., Britner, P. A., \& Blank, T. O. (2014). Parent adaptation and family functioning in relation to narratives of children with chronic illness. Journal of Pediatric Nursing, 29(1), 58-64.

Rostowski, J. (1986). Poziom podobieństwa cech osobowości partnerów jako uwarunkowanie dobranego związku małżeńskiego. Zeszyty Naukowe. Rozprawy i monografie, 74, 115-123.

Schoen, R., \& Weinick, M. (1993). Partner choice in marriages and cohabitations. Journal of Marriage and the Family, 55, 2, 408-414.

Sánchez-Fuentes, M. d. M., Santos-Iglesias, P., \& Sierra, J. C. (2014). A systematic review of sexual satisfaction. International Journal of Clinical and Health Psychology, 14(1), 67-75.

Specjalski, R., Greń, M., Bulińska, K., \& Zielona-Jenek, M. (2014). Satysfakcja seksualna a satysfakcja ze związku u mężczyzn homoseksualnych. Seksuologia Polska, 12(2).

Spanier, G. B., \& Lewis, R. A. (1980). Marital Quality: a Review of the Seventies. Journal of the Marriage and the Family, 825-839.

Stelter, Ż. (2013). Pełnienie ról rodzicielskich wobec dziecka niepełnosprawnego intelektualnie. Warszawa: Difin.

Sprecher, S., \& McKinney, K. (1993). Sexuality, Newbury Park: Sage.

Sprecher, S., Barbee, A., \& Schwartz, P. (1995). „Was it good for you too”?: Gender differences in first sexual intercourse experiences. The Journal of Sex Research, 32, 3-15.

Stelter, Ż. (2014). Satysfakcja małżeńska rodziców dziecka z niepełnosprawnością intelektualną. Psychologia Rozwojowa, 19(1), $117-132$.

Taanila, A., Kokkonen, J., \& Jarvelin, M. R. (1996). The long-term effects of children's early-onset disability on marital relationships. Developmental Medicine and Child Neurology, 38, 567-577.

Upadhyay, S., \& Singh, A. (2009). Psychosocial problems and needs of parents in caring mentally retarded children: the impact of the level of mental retardation of children. Indian Journal of Social Science Research, 6, 1, 103-112.

White, S. G., \& Hatcher, C. (1984). Couple complementarity and similarity: A review of the literature. American Journal of Family Therapy, 12, 1, 15-25.

Witt, W. P., Riley, A. W., \& Coiro, M. J. (2003). Childhood functional status, family stressors, and psychological adjustment among school-aged children with disabilities in the United States. Archives of Pediatric Adolescent Medicine, 157, 687-695.

Woodman, A. C., Mawdsley, H. P., \& Hauser-Cram, P. (2015). Parenting stress and child behavior problems within families of children with developmental disabilities: Transactional relations across 15 years. Research in Developmental Disabilities, 36(1), 264-276.

Wymbs, B. T., Pelham, W. E., Molina, B. S. G., Gnagy, E. M., \& Wilson, T. K. (2008). Rate and predictors of divorce among parents of youths with ADHD. Journal of Consulting and Clinical Psychology, 76, 735-744.

Yucel, D., \& Gassanov, M.A. (2010). Exploring actor and partner correlates of sexual satisfaction among married couples. Social Science Research, 39, 725-738.

Żak-Łykus, A., \& Nawrat, M. (2013). Satysfakcja seksualna, życiowa i partnerska. Opole: Uniwersytet Opolski

Żyta, A. (2011). Życie z zespołem Downa. Narracje biograficzne rodziców rodzeństwa i dorosłych osób z zespołem Downa. Kraków: Oficyna Wydawnicza Impuls. 